POLIIICAL ECONOMY RESEARCH INSTIIUIE

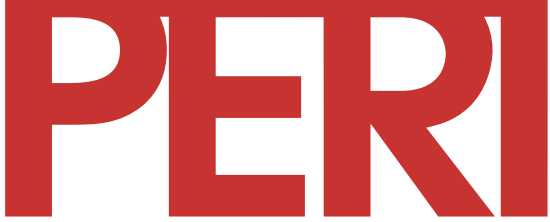

University of Massachusetts Amherst

\title{
An International Index of Child Welfare
}

\author{
Nasrin Dalirazar
}

2002

10th floor Thompson Hall University of Massachusetts Amherst, MA, 01003-7510 Telephone: (413) 545-6355 Facsimile: (413) 545-2921

Email:peri@econs.umass.edu Website:

http://www.umass.edu/peri/

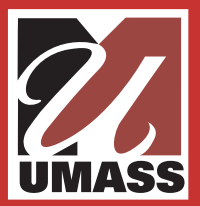


Working Paper No. 40

\title{
An International Index of Child Welfare
}

\author{
Nasrin Dalirazar
}

PERI Program on Development, Peacebuilding, and the Environment Political Economy Research Institute (PERI) University of Massachusetts, Amherst 


\section{Introduction}

This paper develops an international index of child welfare that can be used for comparisons across countries and over time. Values of this index for the year 1998 are presented for 118 countries. The paper is organized as follows. Sections 2 briefly discusses the importance of child welfare both as a means to advance economic development objectives and as an end in itself. Section 3 calculates National Performance Gaps (NPGs), a concept first introduced by UNICEF (1995) to measure child welfare variables relative to international norms based on per capita income. After reviewing some methodological issues, I present estimates of NPGs for five variables: (1) the infant mortality rate; (2) the under-five mortality rate; (3) the percentage of underfive children who are underweight; (4) the primary school enrollment rate; and (5) the percentage of children reaching grade five. Section 4 draws on these NPGs to devise a composite index of child welfare, which I term WINOCENT. Finally, Section 5 offers some concluding remarks.

\section{Child Welfare as Means and as an End}

Studies in the field of child welfare span the whole gamut of social sciences, with contributions from psychologists, demographers, nutritionists, and health and education professionals, as well as economists. The economists' contribution to the literature has been two-fold. Some studies have focused on child welfare as an end in itself, investigating how household behavior and government policies affect child-welfare outcomes. Others have examined child welfare as a means to further other social objectives, investigating the impacts of child health and education on economic growth, productivity, and distributional and gender equity.

\subsection{Child Welfare as an End}

Amartya Sen's work (1984) can be viewed as a cornerstone of the present-day economic literature on child welfare. Sen's "human capabilities" approach recognizes that there are complementarities among various dimensions of well-being. The capability to be well-nourished, for example, depends not only on entitlements to food, but also on entitlements to health care and education. Recent literature has sought to estimate the degree of significance and the directions of causation of these complementarities (Pollitt 1990; Behrman 1996; Behrman et al. 1997; Glewwe 1995, 1996).

One previously neglected issue on which the capabilities approach has helped to shed light is the intra-household distribution of food. Particularly at times of economic hardship, biases against children and women often affect the distribution of food within households (Basu et al. 1995). The potential for bias against children has now been factored into early childhood development (ECD) policy design and formulations (Behrman, 1996; Grantham-McGregor et al. 1991). 
A growing body of literature attests to the efficacy and importance of ECD programs in both developing and the developed countries (Young 1995). Researchers have identified the "windows of opportunity" for the development of children's five core abilities: motor development, emotional control, social attachment, vocabulary, and math and logic (see Figure 1). These windows specify the critical periods in a child's development, when the capability for physical, emotional and cognitive functioning is established. Once a window is closed, interventions in that area will lose their optimal effectiveness. Figure 2 summarizes the needs and areas of intervention for children at three stages: $0-1$ years; 1-3 years; and 3-6 years.

Figure 1: Windows of Opportunity

$\begin{array}{lcccc} & \begin{array}{c}\text { Prenatal } \\ \text { Period }\end{array} & 0-1 & 1-3 & 3-6 \\ \text { Motor Development } & & \text { Years } & \text { Years } & \text { Years } \\ \text { Emotional Control } & & & \\ \text { Social Attachment } & & & \\ \text { Vocabulary } & & & \\ \text { Math/Logic } & & & \end{array}$

Source: van der Gaag (1997)

Figure 2: Needs and Interventions

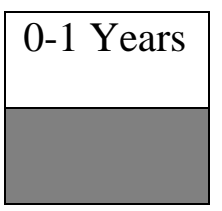

Safe Shelter

Food and

Micronutrients

Health Care

Stimulation

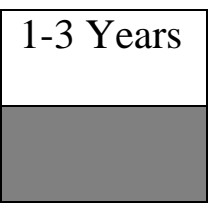

Safe Shelter

Food and

Micronutrients

Health Care

Stimulation

Access to Safe

Water

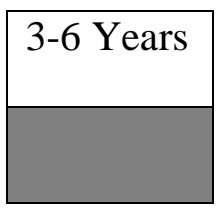

Safe Shelter

Food and

Micronutrients

Health Care

Stimulation

Access to Safe

Water

Preschool Education

Parent Education

Source: van der Gaag (1997) 
In addition to instrumental arguments discussed below, some authors have advocated a "human rights" approach to child welfare, based on ethical and legal norms (Parker, Johnsson, Dall, 1995). Neglect of child rights, it is argued, often has more to do with power relationships, i.e. lack of 'political will,' than with aggregate resource constraints. Here the focus of analysis is on the control and distribution of resources at various levels of society: household, community, state, national, and international. The fact that children cannot care for themselves places a moral obligation on the family, the community, and governments to allocate adequate resources to meet child needs.

In recent years, the rights-based perspective has made increasing inroads into the policy frameworks of international organizations. The 1989 Convention on the Rights of the Child, which by 1995 was ratified by 170 nations, distinguishes between positive rights and negative rights of children. Positive rights are those that have to be produced, such as rights to nutrition, health care, and basic education. These rights depend on resource allocation. A need becomes a positive right when a society is capable of meeting that need, and when fulfillment of that need is essential to human well- being. Negative rights are those that refer not to the provision of goods and services, but rather protection from harm. Negative rights thus do not involve resource costs and are considered to be universal and inviolable.

Given the shortcomings of market forces in meeting child's positive rights, the state can play a crucial role in allocation of resources to this end. Article 24 of the Convention on the Rights of the Child obliges all countries to "diminish infant and child mortality and to combat disease and malnutrition". Article 4 declares that countries "shall undertake such measures [towards this obligation] to the maximum extent of their available resources". This entails a significant implication, namely that there must be a way to assess whether a government is, in fact, guaranteeing positive rights to its children. In 1993, the United Nations' Children's Fund (UNICEF), in its publication The Progress of Nations, introduced one such measure: the National Performance Gap (NPG) to measure the extent to which positive child rights are being honored in relation to available resources as measured by the GNP per capita.

\subsection{Child Welfare as a Means to Advance Other Ends}

The effects of child welfare on other social objectives, including economic growth, productivity, and distributional and gender equity, has also spawned a substantial literature. Here I review several of the more important contributions.

\subsubsection{Economic Growth}

Direct studies of the impact of health and nutrition on national income are rare. Behrman (1996) reports that, controlling for the level of real per capita income, for every year of added life expectancy, the subsequent annual growth rate in total GDP increases by 0.15 percent, exports increase by 0.44 percent, and the population growth rate declines by 0.056 percent. 
Among the various human resource investments, schooling is widely perceived to lead to greater productivity, and hence to economic growth. Studies for the impact of education on economic growth date back to the early 1960s (Schultz, 1961; Denison, 1962; 1967). The contribution of education to increases in output has been estimated at 1 to 3 percent of the percentage output growth per year in Mexico and Brazil, and 16 percent in Argentina (Patrick and Kehrberg, 1973; Pachico and Ashby, 1976). Estimates for Ghana, Malaysia, Nigeria, Kenya, Venezuela, and the Republic of Korea have found this contribution to be in the 12 to 23 percent range (Psacharopoulos and Woodhall, 1985).

In a study of human resource development in Latin America and the Caribbean, Behrman (1996) concluded that for every one-grade increase in average years of schooling, the rate of growth in real GDP increases by about 0.35 percentage points. Furthermore, he found that schooling has effects on international competitiveness and fertility rates, both of which can impact real per capita GNP growth. For every extra grade of schooling, the export growth rate rose by 0.7 percentage points and population growth was lower by 0.2 percentage points. Disaggregating school enrollments, Behrman found that a $30 \%$ difference in primary enrollment rates is associated with a $2.1 \%$ difference in subsequent annual per capita GDP growth, and a 5.4\% difference in subsequent annual export rates. This study also found that a $30 \%$ difference in secondary school enrollments was associated with a reduction in subsequent annual population growth by 1.8 percent.

\subsubsection{Productivity and Wages}

There is ample evidence of a relationship between nutritional status and maximal physical work capacity, as measured by maximal oxygen consumption $\left(\mathrm{VO}_{2} \max \right)$. Studies in East Africa, Sudan, and Colombia (Spurr, 1988; Spurr, Reina, and Barac-Nieto, 1983) have shown that $\mathrm{VO}_{2 \max }$ is positively correlated with output from work. A study by Satyanarayana, Naidu, and Rao (1979) shows that the height and weight of children at age five explains 64 percent of the variance in their current physical work capacity.

There is substantial evidence that early childhood health affects productivity and earnings during adulthood. Health problems during the first years of life can cause physical growth to falter (Martorell et al. 1995, Satyanarayana et al. 1979) and growth deficits as an adult (Bundy, 1997). Studies by Golden (1994) and Martorell et al. (1994) suggest that growth deficits attributed to early childhood ill health result in a reduction in subsequent productivity. A study in rural India found that better nourished boys were paid higher wages, and that men and women with stronger physiological attributes earned as much as $40 \%$ above the normal pay (Satyanarayana, 1980; Satyanarayana et al. 1979). In a study of Ghana, Glewwe and Jacoby (1995) found that for health and nutritional reasons for each year of delay in primary school enrollment, a child lost 3 percent of lifetime wealth. Behrman and his associates (1997), based on a study of data from Pakistan, also found a strong effect: a one-year delay caused a six percent decrease in the value of lifetime earnings. In addition, they found that improved nutrition can yield up to a 32 percent increase independently of the school-delay effect. 
There is also a wealth of evidence on the indirect impact of health and nutrition on productivity via cognitive and educational development. For example, Pollitt (1990), Pollitt et al. (1984), Simeon and Grantham-McGregor (1990), and Grantham-McGregor (1990) have found that severe malnutrition has long-term consequences for mental functioning and educational achievement, and that mild-to-moderate malnutrition can lead to developmental lags that may affect educational achievement. Jamison (1986), Moock et al. (1986), Balderston (1981), Beasley (1995), and a study by UNICEF (1996) have found that low height-for-age is a statistically significant predictor of nonenrollment and slower progress through school. Martorell and colleagues (1992), after controlling for socio-economic circumstances and maternal education, found that slow growth among children up to 3 years old was associated with poorer subsequent school achievement. Several studies suggest that cognitive development is impaired in infants with low birth weight (Saigal et al. 1991, Stjernqvist et al. 1995, Smedler et al. 1992, Hille et al. 1994).

The impact of schooling on wages, earnings, and economic productivity is substantial, with relatively high returns to primary (as opposed to secondary or higher) education. Psacharopoulos (1994), for example, found that one extra year of primary education increases a person's future productivity and wage by 10 to 30 percent. A survey for the World Bank showed that if a farmer completed four years of elementary education, his or her productivity would increase, on average, by 8.7 percent (Lockheed, Jamison, and Lau, 1980; see also Jamison and Moock, 1984).

\subsubsection{Equity: Income Distribution and Gender Inequality}

Child welfare has also been shown to have significant impacts on income distribution and gender inequality. In a cross-national study of Latin America, Behrman (1996) found lower average years of schooling to be associated with a more inequitable distribution of national income. Indeed, his results indicated that education is the variable with the strongest impact on income inequality; variations in years of schooling 'explained' about $25 \%$ of income inequality. Within countries, low schooling was the variable most strongly associated with incomes at the bottom 20 percent: the probability of being in this income category increases as years of schooling decreases. A number of earlier studies of developing countries also reported evidence that increasing education contributes to a more equal income distribution of income (Langoni, 1973; Chiswick et al. 1972; Carnoy et al. 1978).

Behrman (1996) also found that schooling has significant impacts on gender inequality and on the education and health of future generations. High primary school enrollment rates, in particular, are found to be strongly associated with subsequent (20-25 years later) increases in reductions of government expenditures on social services as a percentage of GDP, reductions in low birth weights, reductions in gender differences (favoring males) in infant and under-5 mortality rates, and reductions in gender gaps favoring males in primary school enrollments. For every additional grade of average initial schooling, the primary enrollment rate two decades later is 3.7 percent higher, and 5.6 percent higher for females; the secondary enrollment rate is 5.2 percent higher, and 
5.6 percent higher for females; and adult literacy is 6 percent higher, 6.8 percent higher for females.

At the same time, gender equity has been shown to lead to higher child welfare. For example, Cochran et al. (1980) estimated that one additional year of mother's education leads to a 9 per 1000 reduction in infant mortality, whereas the corresponding figure for father's education was a reduction in infant mortality of 5 per 1000 births. Behrman (1996) reports that an increase by one grade of initial female, relative to male, schooling is estimated to reduce infant mortality by 12 to 13 children per 1000 births; and reduce under- 5 mortality by 20 per 1000 births.

These two lines of argument - child welfare as an end in itself, and as a means to other ends - are not mutually exclusive: each can be seen as adding weight to the other. A merit of the former, rights-based argument, however, is that it directs our attention to the possibility that societal failures to invest in early childhood development may be not merely a result of ignorance and mistakes by policy makers, but also a result of systematic biases that deprive vulnerable sections of society of fundamental rights.

\section{National Performance Gaps and Child Welfare}

This section builds on the pioneering work of UNICEF (1995) to calculate National Performance Gaps (NPGs) for five child-welfare indicators: the infant mortality rate; the under-five mortality rate; under-five malnutrition; the primary-school enrollment rate; and the percentage of children reaching grade five. These NPGs are derived for 112 lower and middle-income countries on the basis of comparisons between actual performance and that predicted by simple regressions of the child-welfare indicators on per capita income.

\subsection{UNICEF's Efforts - Precedent and Shortcomings}

The concept of National Performance Gap was first introduced by the UNICEF in the publication The Progress of Nations, in 1993. This represented the first attempt to assemble an international set of child-welfare indicators that would allow comparisons across countries and over time, controlling for differences in national income per capita. Updated NPG measures were also reported in the 1995 and 1996 editions of the The Progress of Nations. The most comprehensive set of NPGs appeared in the 1996 edition, which reported data for three child welfare indicators - the under-five mortality rate; the percentage of students reaching grade five; and the percentage of children under the age of five who are underweight - for a total of 136 countries.

This paper extends and improves upon these early NPG measures in six ways. First, I calculate NPGs for an expanded set of child welfare indicators, adding the infant mortality rate and the primary school enrollment rate to the three indicators provided by the UNICEF. 
Second, I refine the NPG for the rate of attainment of grade five so as to provide a more robust measure. The UNICEF measure was based on the percentage of primary school entrants who reach grade five. This measure can yield rather odd conclusions, since a country where very few children ever enter primary school, but where all of those who do enroll continue through grade five, performs "better" than one where everyone enters but a few drop out before grade five. To redress this problem, I calculate the percentage of children with the relevant age group who reach grade five, including those who never enrolled in school.

Third, UNICEF calculated NPGs on the basis of data from countries at all income levels, including high-income countries. Here I use data for low-to-middle income countries only, on the grounds that among high-income countries the most relevant indicators of international variations in child welfare pertain to other variables, such as the consumption of tobacco, substance abuse, injuries and deaths from fire arms, and access to health care.

Fourth, the NPGs reported in the UNICEF publications are calculated based on the GNP per capita. As is well known, GNP figures fail to reflect inter-country differences in purchasing power (see Kravis et al. 1978). To control for this, I instead use purchasing power parity-adjusted GNP per capita.

Fifth, the UNICEF studies defined the NPG simply as the absolute difference between the actual values of the child-welfare variable and their expected value, i.e., as the simple residuals when child welfare is regressed on per capita income. The resulting measures do not adequately take into account the differences among countries in their expected values. For example, an under-five mortality rate that exceeds the expected value by 35 deaths per 1000 children arguably means something different when the expected rate is 20 deaths per thousand than it does when the expected rate is 120 deaths per thousand. In addition to such absolute NPGs, therefore, I also present relative NPGs, defined as the absolute gap divided by the expected value, i.e., the percentage difference between actual and expected values.

Finally, in order to calculate the NPGs, I first undertake statistical comparisons of alternative specifications of the relationship between child welfare and per capita income relation, estimated on the basis of several functional forms. In The Progress of Nations, UNICEF describes the method it employed to calculate the NPGs as follows: "Deriving an expected level of performance requires the fitting of a line to country data represented by points on a graph of which one axis is always GNP per capita." Details as to the specifications of this line are not provided in the UNICEF publication. In personal interviews at UNICEF headquarters in New York, I learned that the statistical method used to calculate the NPGs was "locally weighted least squares." This involved fitting two separate linear regression lines to two subsets of the data, truncated at some level of per capita income. The rupture points between the specified ranges were then "smoothed" to yield a curvature between the two estimated linear segments. This procedure is somewhat arbitrary in its specification of the linear form of the segments, the choice of the truncation points, and the ad hoc "smoothing" of the resulting kink in 
the regression line. In this paper, as described below, I test alternative specifications of the child welfare-income relation, choosing the one that provides the best statistical "fit" for use in the calculation of NPGs.

\subsection{Data Sources}

I analyze data for countries with a per capita real income of fifteen thousand dollars or less. I use purchasing power parity-adjusted gross national product per capita (GNPPC), averaged over the years 1996-98, as the variable for real income. This is calculated from data reported by the World Bank's World Development Indicators. I use data on five distinct child-welfare variables: the infant mortality rate (IM); the under-five mortality rate (U5M); the malnourishment rate among children under five years of age (STUNT); the net enrollment rate in primary school (PEN); and the percentage of children reaching the fifth year of school (TRG5).

IM (the infant mortality rate) is defined as the number of children who die between birth and one year of age, per 1000 live births. Data on this variable are taken from the World Health Organization's World Health Report 1999. Most of these data refer to the years 1995 to 1998; in cases where more up-to-date data are not available, I use data from as far back as 1992.

U5M (under-five mortality rate) is the number of children who die between birth and five years of age, per 1000 live births. Data on U5M are also taken from WHO's World Health Report 1999. In cases where data from 1995-1998 were unavailable, I again used U5M data from as far back as 1992.

STUNT refers to the percentage of children under five years of age who are moderately to severely malnourished. According to the World Health Organization (2000b), stunted growth reflects a process of failure to reach linear growth potential as a result of suboptimal health and/or nutritional conditions. The degree of stunting is measured by the height-for-age ratio criterion: the World Health Organization defines moderate stunting as being two standard deviations or more below the median value of height-for-age. The primary sources of data for rate of under-five stunting are the World Health Organization's World Health Report 1999 and Global Database on Child Growth and Malnutrition 2000. Further data are available from UNICEF's State of the World's Children 2000. There are systematic discrepancies, however, between the WHO and UNICEF data. For countries for which data from both the WHO and UNICEF are available, I calculated that the average ratio of the WHO to UNICEF data was 1.6. Therefore, for countries for which the WHO does not report data on stunting but UNICEF does, I used the UNICEF data, scaling it upwards by a factor of 1.6.

PEN (net primary enrollment rate) refers to the total enrollment in primary education in the age group corresponding to the official school age for primary education, divided by the population of the same age group. Data on PEN are taken from UNESCO's World

\footnotetext{
${ }^{1}$ The gross primary enrollment rate refers to the total enrollment in primary education, regardless of age, divided by the population of the age group which officially corresponds to primary schooling. I also
} 
Education Report 2000 for the years 1995-1998; again when data were not available for those years, I used data from as far back as 1992.

The primary source of data on the percentage of primary school entrants who reach grade five (RG5) is the World Bank's World Development Indicators, 2000. In cases where data were unavailable from the World Bank, data were taken from UNICEF's $\underline{\text { State of the }}$ World's Children 2000 and from UNESCO's World Education Report 2000. For countries where data are available from both the World Bank and the United Nations sources, the average ratio of the former to the latter was 0.99 . Therefore, data on this variable from the UNICEF and UNESCO were assimilated with the data from the World Bank without any adjustment. Although RG5, thus defined, is a useful indicator of school performance, for the purposes of this paper, where the focus is on child welfare, a more appropriate indicator is the total percentage of all children in the relevant age group who reach grade five (TRG5). To calculate TRG5, I used data for two variables: the percentage of primary school entrants who reach grade five (RG5) and the net primary enrollment rate $(\mathrm{PEN})$. Let TRG1 = the imputed percentage of all children who enroll in grade one:

$$
(\mathrm{RG} 5)(\mathrm{TRG} 1)=\text { TRG5 }
$$

Assuming a linear school drop-out rate between grades one and five, PEN (for all five years) can be expressed as the simple average of TRG1 and TRG5:

$$
\mathrm{PEN}=(\mathrm{TRG} 1+\mathrm{TRG} 5) / 2
$$

Substituting from equation (1):

$$
\mathrm{PEN}=(\mathrm{TRG} 5 / \mathrm{RG} 5+\mathrm{TRG} 5) / 2
$$

Simplifying and rearranging terms, we get:

$$
\text { TRG5 = 2(PEN) } /(1+1 / \text { RG5) }
$$

The raw data on education indicators appear to be of relatively poor quality. It is doubtful, for example, whether the $100 \%$ enrollment rate reported for Cambodia is accurate. In some cases, the education data may be a better indicator of administrative

examined data on this variable, but I do not report it here as the data on net PEN appear to be more consistent. 
norms than of on-the-ground realities. It is noteworthy that the WHO's World Health Report presents health data in tables distinguished according to their degree of reliability. In contrast, UNESCO's World Education Report by does not offer any indications as to the degree of reliability of the national data.

\subsection{Calculation of the National Performance Gap}

Using ordinary least squares (OLS) regression analysis, I estimated the relationship between these five child-welfare measures and real income, using five alternative specifications: linear, quadratic, log-linear, double-log, and log-quadratic models. Table 1 provides details and summarizes the results, reporting the adjusted $R^{2}$ for all five specifications and all five child-welfare variables ${ }^{2}$. In two of the five cases, the double$\log$ specification (which implies a constant elasticity of child welfare with respect to income) yields the "best" fit, and in the other three cases it comes close to the highest. Accordingly, I used this specification in calculations of the NPGs reported below. The percent of variation thus "explained" by income ranges from $45 \%$ in the case of primary enrollments to $98 \%$ in the case of infant mortality.

The first step in the calculation of the NPGs is the derivation of the expected values for each of the five child-welfare variables, via regressions using the double-log specification. The expected values were converted from natural logarithms to numerical values. The next step was to subtract these expected values from the actual values to yield the NPG in absolute terms. A positive NPG thus indicates that actual values are higher than expected; a negative value indicates the reverse. Finally, this was divided by the expected value to obtain the NPG in relative terms. For the health and nutrition variables (IM, U5M, STUNT) positive NPGs reflect worse performance than that expected on the basis of per capita income; for the education variables (PEN and TRGs) positive values indicate better-than-expected performance.

\subsection{Results}

Tables 2 and 3 present absolute and relative NPGs for the five child-welfare variables, as well as the actual values of these variables and their expected values based on national income per capita. For the health and nutritional variables reported in Table 2, higher values indicate lower child welfare. The results demonstrate the importance of the distinction between absolute and relative NPGs. For example, Guinea Bissau has the poorest infant mortality performance, in absolute terms, with 31 more deaths per 1000 infants than expected on the basis of national income, while Mozambique has the best performance, with 19 fewer than expected. Both countries, however, have extremely high infant mortality rates (in excess of 100 per 1000), underscoring the shortcomings of absolute NPGs as a basis for international comparisons. In terms of relative NPGs, the poorest performer turns out to be Ecuador, where infant mortality was 32 percent above the expected level, and the best performer was Georgia, with infant mortality 28 percent below the expected level.

\footnotetext{
${ }^{2}$ The adjusted $\mathrm{R}^{2}$ statistic is a measure of the percentage of variation in the dependent variable (childwelfare) that is statistically "explained" by variations in the independent variable (per capita income).
} 
For the educational variables reported in Table 3, higher values indicate better child welfare. In terms of relative NPGs, best performers in these two dimensions of education are Malawi and Kyrgyzstan, respectively, while the worst performers are Haiti and the Central African Republic

\section{A Holistic Indicator of Child Welfare: WINOCENT}

Children's well-being has multiple dimensions, encompassing health, nutrition, and education. The composite of these dimensions and the interactions among them ultimately define children's status, providing a fuller picture of their situation than any single dimension. To present a holistic indicator of child welfare, I now derive a quantitative measure that I call WINOCENT, standing for the "Welfare Index of Children in their Entirety." Like established social and economic indexes such as the United Nations Development Programme's HDI (Human Development Index) and GEM (Gender Equality Measure), WINOCENT provides a convenient measure of a multidimensional phenomenon, in this case children's welfare. It thereby provides a tool for gauging the extent to which the needs of children as a whole are met. It is hoped that WINOCENT will be useful to policy-makers, and particularly to those interested in the human-capabilities approach to development. The WINOCENT index is the simple average of the relative NPGs for five child-welfare indicators: the infant mortality rate; the under-five mortality rate; the rate of under-five malnourishment; the primary-school enrollment rate; and the percentage of children reaching grade five. The signs of the various NPGs were reversed for the health and nutrition variables, so that higher values uniformly denote greater child welfare. Thus:

$$
\text { WINOCENT }=\left(-\mathrm{NPG}_{\mathrm{IM}} \%-\mathrm{NPG}_{\mathrm{U} 5 \mathrm{M}} \%-\mathrm{NPG}_{\mathrm{STUNT}} \%+\mathrm{NPG}_{\mathrm{PEN}} \%+\mathrm{NPG}_{\mathrm{TRG}} \%\right) / 5
$$

Table 4 presents the WINOCENT index, with countries ranked from the highest (best performance) to the lowest (worst performance). The index is calculated only for countries for which data on all five child-welfare indicators are available. The best performer is Georgia, with a WINOCENT of 42; that is, child welfare in Georgia is, on average, $42 \%$ higher than would be expected on the basis of its national income. The worst performer is Botswana, with a WINOCENT of minue 120; that is, child welfare is less than half of what would be expected on the basis of national income. In the Americas, the WINOCENT ranges from 32 in Jamaica to minus 59 in Guatemala. In Asia and Pacific, it ranges from 30 in Sri Lanka to minus 38 in Malaysia. In Eastern Europe and Central Asia and Europe, the WINOCENT is positive for all countries. In Middle East and North Africa, the WINOCENT ranges from 17 in the expected level in the Syrian Arab Republic to minus 28 in Turkey.

\footnotetext{
${ }^{3}$ The accuracy of Malawi's reported PEN of $99 \%$ is doubtful, however. As noted above, the educational data generally appear to be of poorer quality than the health data.
} 


\section{Summary}

This paper has reintroduced and developed the concept of the National Performance Gap as an indicator of child welfare, building upon the pioneering works of UNICEF, which first introduced the concept. I have attempted to update that work and improve upon it in several respects, including the use of purchasing power parity-adjusted GNP per capita as the measure for national income; the use of a double-log specification of the child welfare-income relation, chosen after goodness-of-fit comparisons with alternatives; and the computation of relative as well as absolute NPGs.

Based on these results, a holistic child welfare index, WINOCENT, was constructed to represent children's overall well-being. Like the national performance gaps from which it is constructed, WINOCENT is a tool for monitoring progress in child welfare while controlling for the level of per capita income. In this sense, it provides a useful picture of children's status for making inter-country and inter-regional comparisons. The NPGs and WINOCENT could be of interest to health, nutrition, and education analysts at the national and international levels, as tools for planning and evaluating early childhood interventions. The WINOCENT can also serve as a baseline on children's status for all involved in promoting and protecting children's rights and interests worldwide.

This paper also sheds light on the role of one basic determinant of international variations in child welfare: national income per capita. Clearly, however, much variation remains to be explained. The NPGs can be used to study and evaluate reasons for divergences in child-welfare among countries and over time. Potential explanatory variables of interest include some that are readily susceptible to policy interventions (e.g., government expenditure on health and education), and others such as income distribution and the extent of civil and political liberties that are more "structural" and hence less amenable to short-run policy remedies. In future research, I intend to assess the relative importance of these determinants. 
Table 1 Goodness-of-Fit For Alternative Specifications of Child-Welfare vs. Income Curve ( $\left.\mathbf{R}^{2}\right)$

\begin{tabular}{|c|c|c|c|c|c|}
\hline Specification & IMR & U5M & STUNT & PEN & TRG5 \\
\hline $\begin{array}{l}\text { Linear } \\
\text { CWI }_{i}=\alpha+\beta\left(\text { GNPPC }_{i}\right)+v\end{array}$ & 0.52 & 0.38 & 0.47 & 0.30 & 0.44 \\
\hline $\begin{array}{l}\text { Quadratic } \\
\mathrm{CWI}_{i}=\alpha+\beta_{1}\left(\mathrm{GNPPC}_{i}\right)+\beta_{2}\left(\mathrm{GNPPC}_{i}\right)^{2}+v\end{array}$ & 0.75 & 0.54 & 0.51 & 0.46 & 0.62 \\
\hline $\begin{array}{l}\text { Log-Linear } \\
\ln _{n} \mathrm{CWI}_{i}=\alpha+\beta\left(\mathrm{GNPPC}_{i}\right)+v\end{array}$ & 0.80 & 0.54 & 0.53 & 0.26 & 0.36 \\
\hline $\begin{array}{l}\text { Double-Log } \\
\ln _{n} \mathrm{CWI}_{i}=\boldsymbol{\alpha}+\boldsymbol{\beta}\left(\ln _{n} \mathrm{GNPPC}_{i}\right)+\boldsymbol{v}\end{array}$ & 0.98 & 0.65 & 0.48 & 0.45 & 0.57 \\
\hline $\begin{array}{l}\text { Log-Quadratic } \\
\ln C W I_{i}=\alpha+\beta_{1}\left(\ln _{n} \mathrm{GNPPC}_{i}\right)+\beta_{2}\left(\ln _{n} \mathrm{GNPPC}_{i}\right)^{2}\end{array}$ & 0.93 & 0.59 & 0.53 & 0.40 & 0.54 \\
\hline
\end{tabular}

Key:

$\mathrm{CWI}_{\mathrm{i}}=$ child welfare indicator for the ith

country

GNPPC $_{i}=$ purchasing-power adjusted GNP per capita for the

ith country

$\mathrm{IMR}=$ infant mortality rate

$\mathrm{U} 5 \mathrm{M}=$ under-five mortality rate

STUNT = under-five rate of malnutrition

$\mathrm{PEN}=$ net primary enrollment rate

TRG5 = percentage of children reaching grade

five

$\boldsymbol{\alpha}=$ intercept term

$\beta=$ regression coefficient

$v=$ error term 
Table 2 National Performance Gap: Health and Nutritional Dimensions of Child Welfare, 1995-98

\begin{tabular}{|c|c|c|c|c|c|c|c|c|c|c|c|c|}
\hline \multirow[t]{3}{*}{ Country } & \multicolumn{4}{|c|}{ Infant Mortality (IM) } & \multicolumn{4}{|c|}{ Under-Five Mortality (U5M) } & \multicolumn{4}{|c|}{ Under-Five Malnutrition (STUNT) } \\
\hline & \multirow[t]{2}{*}{ Actual } & \multirow[t]{2}{*}{ Expected } & \multirow{2}{*}{\multicolumn{2}{|c|}{\begin{tabular}{|c|} 
NPG \\
Absolute Relative \\
\end{tabular}}} & \multirow[t]{2}{*}{ Actual } & \multirow[t]{2}{*}{ Expected } & \multirow{2}{*}{\multicolumn{2}{|c|}{$\begin{array}{c}\text { NPGusm } \\
\text { Absolute Relative } \\
\end{array}$}} & \multirow[t]{2}{*}{ Actual } & \multirow[t]{2}{*}{ Expected } & \multicolumn{2}{|c|}{ NPG } \\
\hline & & & & & & & & & & & Absolute & e Relative \\
\hline Americas & & & & & & & & & & & & \\
\hline Argentina & 10 & 11 & -1 & -10 & 22 & 15 & 7 & 47 & 5 & 9 & -4 & -45 \\
\hline Bolivia & 43 & 37 & 6 & 17 & 78 & 51 & 27 & 53 & 29 & 22 & 7 & 32 \\
\hline Brazil & 17 & 17 & 0 & 0 & 40 & 23 & 17 & 74 & 10 & 12 & -2 & -17 \\
\hline Chile & 13 & 11 & 2 & 19 & 12 & 14 & -2 & -15 & 2 & 9 & -7 & -78 \\
\hline Colombia & 18 & 17 & 1 & 6 & 28 & 23 & 5 & 22 & 15 & 12 & 3 & 25 \\
\hline Costa Rica & 18 & 18 & 0 & 0 & 15 & 23 & -8 & -35 & 6 & 12 & -6 & -50 \\
\hline Dominican Rep. & 24 & 24 & 0 & 0 & 49 & 32 & 17 & 54 & 11 & 15 & -4 & -27 \\
\hline Ecuador & 33 & 25 & 8 & 32 & 37 & 33 & 4 & 13 & 33 & 16 & 18 & 113 \\
\hline El Salvador & 25 & 31 & -6 & -20 & 36 & 42 & -6 & -15 & 23 & 19 & 4 & 22 \\
\hline Guatemala & 29 & 27 & 2 & 8 & 52 & 36 & 16 & 45 & 50 & 17 & 33 & 195 \\
\hline Haiti & 64 & 71 & -7 & -10 & 116 & 99 & 17 & 18 & 32 & 35 & -3 & -9 \\
\hline Honduras & 40 & 43 & -3 & -7 & 46 & 58 & -12 & -21 & 40 & 24 & 16 & 67 \\
\hline Jamaica & 30 & 30 & 0 & 0 & 24 & 40 & -16 & -40 & 7 & 18 & -11 & -62 \\
\hline Mexico & 15 & 15 & 0 & 0 & 35 & 19 & 16 & 85 & 23 & 11 & 12 & 110 \\
\hline Nicaragua & 48 & 51 & -3 & -6 & 42 & 71 & -29 & -41 & 24 & 27 & -3 & -12 \\
\hline Panama & 21 & 18 & 3 & 17 & 25 & 23 & 2 & 9 & 9 & 12 & -3 & -25 \\
\hline Paraguay & 24 & 27 & -3 & -12 & 27 & 35 & -8 & -23 & 14 & 17 & -3 & -18 \\
\hline Peru & 25 & 24 & 1 & 5 & 47 & 32 & 15 & 47 & 26 & 16 & 10 & 63 \\
\hline Trinidad\&Tob & 15 & 17 & -2 & -12 & 18 & 22 & -4 & -19 & 5 & 12 & -7 & -59 \\
\hline Uruguay & 13 & 14 & -1 & -8 & 19 & 18 & 1 & 6 & 9 & 10 & -1 & -10 \\
\hline Venezuela & 19 & 15 & 4 & 27 & 25 & 20 & 5 & 25 & 13 & 11 & 2 & 19 \\
\hline Asia and Pacific & & & & & & & & & & & & \\
\hline Bangladesh & 63 & 76 & -13 & -18 & 96 & 106 & -10 & -10 & 55 & 36 & 19 & 53 \\
\hline Cambodia & 70 & 71 & -1 & -2 & 143 & 99 & 44 & 45 & 50 & 35 & 15 & 43 \\
\hline China & 32 & 32 & 0 & 0 & 36 & 43 & -7 & -17 & 31 & 19 & 12 & 64 \\
\hline India & 45 & 53 & -8 & -16 & 83 & 73 & 10 & 14 & 52 & 28 & 24 & 86 \\
\hline Indonesia & 39 & 33 & 6 & 19 & 52 & 44 & 8 & 19 & 42 & 20 & 22 & 110 \\
\hline Korea Rep. & 9 & 9 & 0 & 0 & 11 & 12 & -1 & -9 & 7 & & & \\
\hline Lao PDR & 54 & 65 & -11 & -17 & 111 & 76 & 35 & 47 & 47 & 32 & 15 & 47 \\
\hline Malaysia & 15 & 13 & 2 & 16 & 12 & 17 & -5 & -30 & 30 & 10 & 20 & 200 \\
\hline Mongolia & 61 & 58 & 3 & 6 & 60 & 80 & -20 & -25 & 25 & 30 & -5 & -17 \\
\hline Nepal & 73 & 79 & -6 & -8 & 107 & 110 & -3 & -3 & 48 & 37 & 11 & 30 \\
\hline Pakistan & 55 & 57 & -2 & -4 & 120 & 79 & 41 & 52 & 61 & 30 & 31 & 104 \\
\hline Papua New Guinea & 43 & 39 & 4 & 11 & 76 & 53 & 23 & 44 & 43 & 22 & 21 & 96 \\
\hline Philippines & 27 & 28 & -1 & -4 & 40 & 38 & 2 & 6 & 33 & 18 & 15 & 84 \\
\hline Sri Lanka & 33 & 38 & -5 & -14 & 18 & 52 & -34 & -66 & 24 & 22 & 2 & 10 \\
\hline Thailand & 19 & 18 & 1 & 6 & 33 & 23 & 10 & 44 & 16 & 13 & 3 & 24 \\
\hline
\end{tabular}




\begin{tabular}{|c|c|c|c|c|c|c|c|c|c|c|c|c|}
\hline \multirow[t]{3}{*}{ Country } & \multicolumn{4}{|c|}{ Infant Mortality (IM) } & \multicolumn{4}{|c|}{ Under-Five Mortality (U5M) } & \multicolumn{4}{|c|}{ Under-Five Malnutrition (STUNT) } \\
\hline & \multirow{2}{*}{\multicolumn{2}{|c|}{ Actual Expected }} & \multicolumn{2}{|c|}{$N P G_{I M}$} & \multirow[t]{2}{*}{ Actual } & \multirow[t]{2}{*}{ Expected } & \multicolumn{2}{|c|}{ NPGu5M } & \multirow[t]{2}{*}{ Actual } & \multirow[t]{2}{*}{ Expected } & \multicolumn{2}{|c|}{ NPG } \\
\hline & & & Absolute & Relative & & & Absolute & Relative & & & Absolute & Relative \\
\hline Vietnam & 54 & 57 & -3 & -6 & 42 & 79 & -37 & -47 & 47 & 30 & 17 & 57 \\
\hline \multicolumn{13}{|l|}{ Central Asia } \\
\hline Armenia & 45 & 43 & 2 & 5 & 18 & 58 & -40 & -69 & 12 & 24 & -12 & -50 \\
\hline Azerbaijan & 43 & 54 & -11 & -21 & 21 & 74 & -53 & -72 & 22 & 28 & -6 & -22 \\
\hline Kazakhstan & 24 & 28 & -4 & -15 & 29 & 37 & -8 & -22 & 16 & 17 & -1 & -6 \\
\hline Kyrgyzstan & 42 & 45 & -3 & -7 & 41 & 61 & -20 & -33 & 25 & 25 & 0 & 0 \\
\hline Tajikistan & 82 & 86 & -4 & -5 & 33 & 121 & -88 & -73 & 40 & 40 & 0 & 0 \\
\hline Uzbekistan & 45 & 43 & 2 & 5 & 29 & 58 & -29 & -50 & 31 & 24 & 7 & 30 \\
\hline \multicolumn{13}{|l|}{ Europe } \\
\hline Albania & 34 & 39 & -5 & -13 & 31 & 53 & -22 & -42 & 15 & 22 & -7 & -32 \\
\hline Belarus & 17 & 21 & -4 & -20 & 14 & 27 & -13 & -49 &.. &.. &.. &.. \\
\hline Bulgaria & 22 & 24 & -2 & -9 & 15 & 33 & -18 & -55 &.. &.. &.. &.. \\
\hline Croatia & 16 & 20 & -4 & -20 & 10 & 27 & -17 & -63 & 1 & 14 & -13 & -93 \\
\hline Czech Republic & 10 & 11 & -1 & -10 & 6 & 14 & -8 & -58 & 2 & 9 & -7 & -78 \\
\hline Estonia & 15 & 19 & -4 & -22 & 12 & 25 & -13 & -52 &.. &.. &.. &.. \\
\hline Georgia & 29 & 40 & -11 & -28 & 20 & 55 & -35 & -64 & 12 & 23 & -11 & -48 \\
\hline Greece & 9 & 9 & 0 & 0 & 8 & 12 & -4 & -34 &.. &.. &.. &.. \\
\hline Hungary & 12 & 15 & -3 & -20 & 12 & 19 & -7 & -37 & 3 & 11 & -8 & -73 \\
\hline Latvia & 19 & 24 & -5 & -21 & 19 & 31 & -12 & -39 &.. &.. &.. &.. \\
\hline Lithuania & 17 & 22 & -5 & -23 & 12 & 29 & -17 & -59 &.. &.. &.. &.. \\
\hline Macedonia & 24 & 28 & -4 & -15 & 18 & 37 & -19 & -52 &.. &.. & .. & .. \\
\hline Moldova & 46 & 57 & -11 & -20 & 22 & 78 & -56 & -72 &.. &.. &.. &.. \\
\hline Poland & 15 & 17 & -2 & -12 & 11 & 22 & -11 & -50 &.. & .. &.. &.. \\
\hline Portugal & 9 & 9 & 0 & 0 & 8 & 11 & -3 & -28 &.. &.. &.. &.. \\
\hline Romania & 19 & 22 & -3 & -14 & 25 & 29 & -4 & -14 & 8 & 15 & -7 & -47 \\
\hline Russian Federation & 18 & 22 & -4 & -19 & 20 & 29 & -9 & -32 & 13 & 15 & -2 & -14 \\
\hline Slovak Republic & 12 & 14 & -2 & -15 & 10 & 18 & -8 & -45 &.. &.. &.. &.. \\
\hline Slovenia & 9 & 10 & -1 & -10 & 7 & 12 & -5 & -42 &.. &.. &.. & .. \\
\hline Ukraine & 31 & 39 & -8 & -21 & 17 & 53 & -36 & -68 &.. &.. &.. & .. \\
\hline \multicolumn{12}{|l|}{$\begin{array}{l}\text { Middle East } \\
\text { and North Africa }\end{array}$} & 20 \\
\hline Egypt Arab Rep. & 31 & 33 & -2 & -7 & 59 & 44 & 15 & 35 & 25 & 20 & 5 & 25 \\
\hline Iran Islamic Rep. & 21 & 20 & 1 & 5 & 33 & 26 & 7 & 27 & 19 & 14 & 5 & 36 \\
\hline Jordan & 37 & 32 & 5 & 16 & 31 & 43 & -12 & -28 & 16 & 19 & -3 & -16 \\
\hline Lebanon & 25 & 20 & 5 & 25 & 30 & 26 & 4 & 16 & 12 & 14 & -2 & -15 \\
\hline Morocco & 31 & 31 & 0 & 0 & 61 & 42 & 19 & 46 & 24 & 19 & 5 & 27 \\
\hline Saudi Arabia & 11 & 12 & -1 & -9 & 26 & 15 & 11 & 74 &.. & & & \\
\hline Sudan & 70 & 69 & 1 & 2 & 105 & 96 & 9 & 10 & 34 & 34 & 0 & 0 \\
\hline Syrian Arab Rep. & 36 & 34 & 2 & 6 & 32 & 46 & -14 & -31 & 21 & 20 & 1 & 5 \\
\hline
\end{tabular}




\begin{tabular}{|c|c|c|c|c|c|c|c|c|c|c|c|c|}
\hline \multirow[t]{3}{*}{ Country } & \multicolumn{4}{|c|}{ Infant Mortality (IM) } & \multicolumn{4}{|c|}{ Under-Five Mortality (U5M) } & \multicolumn{4}{|c|}{ Under-Five Malnutrition (STUNT) } \\
\hline & \multirow[t]{2}{*}{ Actual } & \multirow[t]{2}{*}{ Expected } & \multicolumn{2}{|c|}{$N P G_{M M}$} & \multirow[t]{2}{*}{ Actual } & \multirow[t]{2}{*}{ Expected } & \multirow{2}{*}{\multicolumn{2}{|c|}{\begin{tabular}{|c|c|}
\multicolumn{2}{|c}{ NPG G5M } \\
Absolute Relative
\end{tabular}}} & \multirow[t]{2}{*}{ Actual } & \multirow[t]{2}{*}{ Expected } & \multicolumn{2}{|c|}{ NPG } \\
\hline & & & Absolute & Relative & & & & & & & Absolut & e Relative \\
\hline Tunisia & 20 & 22 & -2 & -10 & 32 & 29 & 3 & 11 & 22 & 15 & 7 & 47 \\
\hline Turkey & 17 & 17 & 0 & 0 & 42 & 23 & 19 & 83 & 20 & 12 & 8 & 67 \\
\hline Yemen Rep. & 122 & 116 & 6 & 6 & 96 & 165 & -69 & -42 & 51 & 50 & 1 & 2 \\
\hline Sub-Saharan Africa & & & & & & & & & & & & \\
\hline Angola & 85 & 91 & -6 & -7 & 204 & 128 & 76 & 60 & 53 & 42 & 11 & 27 \\
\hline Benin & 97 & 79 & 18 & 23 & 140 & 111 & 29 & 27 & 25 & 38 & -13 & -35 \\
\hline Botswana & 19 & 16 & 3 & 19 & 105 & 21 & 84 & 400 & 29 & 12 & 17 & 142 \\
\hline Burkina Faso & 96 & 92 & 4 & 5 & 210 & 130 & 80 & 62 & 33 & 42 & -9 & -22 \\
\hline Burundi & 140 & 139 & 1 & 1 & 196 & 198 & -2 & -2 & 52 & 57 & -5 & -9 \\
\hline Cameroon & 63 & 57 & 6 & 11 & 150 & 78 & 72 & 93 & 26 & 29 & -3 & -11 \\
\hline Central Afr. Rep. & 78 & 70 & 8 & 12 & 162 & 98 & 64 & 66 & 28 & 34 & -6 & -18 \\
\hline Chad & 98 & 97 & 1 & 2 & 172 & 136 & 36 & 27 & 40 & 43 & -3 & -7 \\
\hline Congo Dem. Rep. & 111 & 111 & 0 & 0 & 141 & 157 & -16 & -11 & 21 & 48 & -3 & -7 \\
\hline Congo Rep. & 98 & 75 & 23 & 31 & 143 & 105 & 38 & 37 & 44 & 36 & -15 & -42 \\
\hline Côte d'Ivoire & 60 & 58 & 2 & 4 & 143 & 80 & 63 & 79 & 24 & 30 & -6 & -20 \\
\hline Eritrea & 86 & 87 & -1 & -2 & 90 & 121 & -31 & -26 & 38 & 40 & -2 & -5 \\
\hline Ethiopia & 139 & 155 & -16 & -11 & 173 & 222 & -49 & -23 & 64 & 61 & 3 & 5 \\
\hline Gabon & 19 & 18 & 1 & 6 & 132 & 23 & 109 & 474 & & .. & .. & .. \\
\hline Gambia & 62 & 66 & -4 & -7 & 78 & 89 & -11 & -13 & 30 & 33 & -3 & -10 \\
\hline Ghana & 52 & 54 & -2 & -4 & 96 & 75 & 21 & 28 & 26 & 28 & -2 & -8 \\
\hline Guinea & 53 & 54 & -1 & -2 & 184 & 74 & 110 & 149 & 29 & 28 & 1 & 4 \\
\hline Guinea Bissau & 137 & 106 & 31 & 30 & 205 & 150 & 55 & 37 & 23 & 46 & -9 & -20 \\
\hline Kenya & 87 & 81 & 6 & 8 & 124 & 114 & 10 & 9 & 34 & 38 & -4 & -11 \\
\hline Lesotho & 43 & 41 & 2 & 5 & 144 & 56 & 88 & 158 & 44 & 23 & 21 & 92 \\
\hline Madagascar & 110 & 101 & 9 & 9 & 146 & 143 & 3 & 3 & 50 & 45 & 5 & 12 \\
\hline Malawi & 142 & 128 & 14 & 11 & 229 & 183 & 46 & 26 & 48 & 53 & -5 & -10 \\
\hline Mali & 119 & 120 & -1 & -1 & 218 & 170 & 48 & 29 & 30 & 51 & -21 & -42 \\
\hline Mauritania & 59 & 56 & 3 & 6 & 140 & 77 & 63 & 82 & 40 & 29 & 11 & 38 \\
\hline Mauritius & 14 & 13 & 1 & 8 & 22 & 17 & 5 & 30 & 10 & 10 & 0 & 0 \\
\hline Mozambique & 110 & 129 & -19 & -15 & 213 & 183 & 30 & 17 & 36 & 54 & -18 & -34 \\
\hline Namibia & 20 & 20 & 0 & 0 & 112 & 27 & 85 & 315 & 29 & 14 & 15 & 108 \\
\hline Niger & 111 & 103 & 8 & 8 & 250 & 146 & 104 & 72 & 39 & 46 & -7 & -16 \\
\hline Nigeria & 110 & 104 & 6 & 6 & 119 & 146 & -27 & -19 & 43 & 46 & -3 & -7 \\
\hline Senegal & 67 & 60 & 7 & 12 & 121 & 82 & 39 & 48 & 23 & 30 & -7 & -24 \\
\hline Sierra Leone & 171 & 175 & -4 & -3 & 283 & 252 & 31 & 13 & 35 & 67 & -32 & -48 \\
\hline South Africa & 14 & 15 & -1 & -7 & 83 & 19 & 64 & 337 & 23 & 11 & 12 & 110 \\
\hline Tanzania & 159 & 148 & 11 & 8 & 136 & 211 & -75 & -36 & 43 & 59 & -16 & -28 \\
\hline
\end{tabular}




\begin{tabular}{|c|c|c|c|c|c|c|c|c|c|c|c|c|}
\hline \multirow[t]{3}{*}{ Country } & \multicolumn{4}{|c|}{ Infant Mortality (IM) } & \multicolumn{4}{|c|}{ Under-Five Mortality (U5M) } & \multicolumn{4}{|c|}{ Under-Five Malnutrition (STUNT) } \\
\hline & \multirow[t]{2}{*}{ Actua } & \multirow[t]{2}{*}{ Expected } & \multicolumn{2}{|c|}{$\mathrm{NPG}_{\mathrm{IM}}$} & \multirow[t]{2}{*}{ Actual } & \multirow[t]{2}{*}{ Expected } & \multirow{2}{*}{\multicolumn{2}{|c|}{\begin{tabular}{c|c|c|}
\multicolumn{2}{c}{ NPG } \\
solute
\end{tabular}}} & \multirow[t]{2}{*}{ Actual } & \multirow[t]{2}{*}{ Expected } & \multicolumn{2}{|c|}{ NPG } \\
\hline & & & Absolute & Relative & & & & & & & Absolute & Relative \\
\hline Togo & 65 & 62 & 3 & 5 & 144 & 85 & 59 & 70 & 34 & 31 & 3 & 10 \\
\hline Uganda & 80 & 81 & -1 & -2 & 170 & 113 & 57 & 51 & 38 & 38 & 0 & 0 \\
\hline Zambia & 119 & 105 & 14 & 14 & 192 & 148 & 44 & 30 & 42 & 46 & -4 & -9 \\
\hline Zimbabwe & 38 & 42 & -4 & -10 & 125 & 57 & 68 & 120 & 21 & 23 & -2 & -9 \\
\hline
\end{tabular}

Sources:

WHO, World Health Report 1999.

World Bank, World Development Indicators 1997, 1998, 2000.

WHO, Global Database on Child Growth and Malnutrition 2000.

UNICEF, State of the World's Children 2000. STUNT - Moderate to severe malnourishment

.. Indicates data were not available for the country. 
Table 3 National Performance Gap: Educational Dimensions of Child Welfare, 1995-98

\begin{tabular}{|c|c|c|c|c|c|c|c|c|}
\hline \multirow[t]{3}{*}{ Country } & \multicolumn{4}{|c|}{ Primary Enrollment Rate (PEN) } & \multicolumn{4}{|c|}{ \% Reaching Grade Five (TRG5) } \\
\hline & \multirow[t]{2}{*}{ Actual } & \multirow[t]{2}{*}{ Expected } & \multirow{2}{*}{\multicolumn{2}{|c|}{\begin{tabular}{|c|} 
NPG \\
Absolute Relative
\end{tabular}}} & \multirow[t]{2}{*}{ Actual } & \multirow[t]{2}{*}{ Expected } & \multicolumn{2}{|c|}{$\mathrm{NPG}_{\text {TRG5 }}$} \\
\hline & & & & & & & Absolute & Relative \\
\hline Americas & & & & & & & & \\
\hline Argentina & 100 & 100 & 0 & 0 & & & & \\
\hline Bolivia & 97 & 75 & 22 & 30 & 73 & 63 & 10 & 16 \\
\hline Brazil & 97 & 96 & 1 & 2 & 81 & 92 & -11 & -12 \\
\hline Chile & 90 & 100 & -10 & -10 & 90 & 100 & -10 & -10 \\
\hline Colombia & 89 & 96 & -7 & -8 & 76 & 92 & -16 & -18 \\
\hline Costa Rica & 89 & 95 & -6 & -7 & 84 & 91 & -7 & -8 \\
\hline Dominican Rep. & 91 & 87 & 4 & 5 & 67 & 79 & -12 & -16 \\
\hline Ecuador & 100 & 85 & 15 & 18 & 92 & 76 & 16 & 22 \\
\hline El Salvador & 89 & 80 & 9 & 12 & 78 & 69 & 9 & 14 \\
\hline Guatemala & 74 & 83 & -9 & -11 & 50 & 74 & -24 & -33 \\
\hline Haiti & 20 & 62 & -42 & -68 & 13 & 46 & -33 & -72 \\
\hline Honduras & 88 & 72 & 16 & 23 & 66 & 59 & 7 & 12 \\
\hline Jamaica & 96 & 81 & 15 & 19 & 95 & 70 & 25 & 36 \\
\hline Mexico & 100 & 100 & 0 & 0 & 93 & 99 & -6 & -7 \\
\hline Nicaragua & 79 & 68 & 11 & 17 & 57 & 54 & 3 & 6 \\
\hline Panama & 90 & 95 & -5 & -6 & 82 & 91 & -9 & -10 \\
\hline Paraguay & 96 & 84 & 12 & 15 & 85 & 74 & 11 & 15 \\
\hline Peru & 94 & 87 & 7 & 9 & .. & |. & .. & .. \\
\hline Trinidad \& Tobago & 100 & 96 & 4 & 5 & 99 & 93 & 6 & 7 \\
\hline Uruguay & 94 & 100 & -6 & -6 & 94 & 100 & -6 & -6 \\
\hline Venezuela & 83 & 100 & -17 & -17 & 79 & 98 & -19 & -20 \\
\hline Asia and Pacific & & & & & & & & \\
\hline Bangladesh & 75 & 61 & 14 & 23 & 48 & 45 & 3 & 7 \\
\hline Cambodia & 100 & 62 & 38 & 62 & 66 & 47 & 19 & 41 \\
\hline China & 100 & 79 & 21 & 27 & 97 & 68 & 29 & 43 \\
\hline India & 77 & 68 & 9 & 14 & 58 & 54 & 4 & 8 \\
\hline Indonesia & 99 & 78 & 21 & 27 & 93 & 67 & 26 & 39 \\
\hline Korea Rep. & 100 & 100 & 0 & 0 & 100 & 100 & 0 & 0 \\
\hline Lao PDR & 73 & 64 & 9 & 15 & 53 & 49 & 4 & 9 \\
\hline Malaysia & 100 & 100 & 0 & 0 & 100 & 100 & 0 & 0 \\
\hline Mongolia & 85 & 66 & 19 & 29 & 81 & 51 & 30 & 59 \\
\hline Nepal & 78 & 60 & 18 & 30 & 54 & 44 & 10 & 23 \\
\hline Pakistan &.. & +5 &.. & .. &.. & .. & 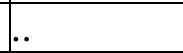 & .. \\
\hline Papua New Guinea & 79 & 75 & 4 & 6 & 59 & 62 & -3 & -5 \\
\hline Philippines & 100 & 82 & 18 & 22 & 83 & 72 & 11 & 16 \\
\hline Sri Lanka & 100 & 75 & 25 & 34 & 91 & 63 & 28 & 45 \\
\hline Thailand & 88 & 95 & -7 & -8 & 83 & 91 & -8 & -9 \\
\hline
\end{tabular}


19

\begin{tabular}{|c|c|c|c|c|c|c|c|c|}
\hline \multirow[t]{2}{*}{ Country } & \multicolumn{4}{|c|}{ Primary Enrollment Rate (PEN) } & \multicolumn{4}{|c|}{ \% Reaching Grade Five (TRG5) } \\
\hline & \multicolumn{2}{|c|}{ Actual Expected } & \multicolumn{2}{|c|}{ NPG } & Actual & Expected & \multicolumn{2}{|c|}{ NPG TRG5 $_{\text {Th }}$} \\
\hline Vietnam & 100 & 66 & 34 & 52 & & & & .. \\
\hline Central Asia & & & & & & & & \\
\hline Armenia & & .. & &. & & .. &.. & .. \\
\hline Azerbaijan & $\cdot$. &.. &.. &.. &.. &.. & .. &.. \\
\hline Kazakhstan & &.. & & & & 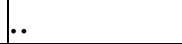 & .. & .. \\
\hline Kyrgyzstan & 100 & 71 & 29 & 41 & 99 & 58 & 41 & 71 \\
\hline Tajikistan & 93 & 59 & 34 & 58 &. &.. &.. &.. \\
\hline Uzbekistan & 1. & .. & $\ldots$ &.. & .. & .. & .. &.. \\
\hline Europe & & & & & & & & \\
\hline Albania & 96 & 75 & 21 & 28 & 86 & 62 & 24 & 39 \\
\hline Belarus & 85 & 90 & -5 & -6 & 85 & 84 & 1 & 2 \\
\hline Bulgaria & 98 & 86 & 12 & 14 & 94 & 77 & 17 & 23 \\
\hline Croatia & 100 & 91 & 9 & 10 & 99 & 85 & 14 & 17 \\
\hline Czech Republic & 100 & 100 & 0 & 0 & 99 & 100 & -1 & -1 \\
\hline Estonia & 100 & 93 & 7 & 8 & 99 & 88 & 11 & 13 \\
\hline Georgia & 89 & 74 & 15 & 21 & 89 & 61 & 28 & 46 \\
\hline Greece & 100 & 100 & 0 & 0 & 100 & 100 & 0 & 0 \\
\hline Hungary & 98 & 100 & -2 & -2 & 98 & 100 & -2 & -2 \\
\hline Latvia & 100 & 87 & 13 & 15 & 99 & 79 & 20 & 26 \\
\hline Lithuania & & .. & & &.. & $\ddot{*}$ & .. & .. \\
\hline Macedonia & 95 & 83 & 12 & 15 & 93 & 73 & 20 & 28 \\
\hline Moldova & 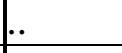 &.. &.. &. & .. &.. &.. & .. \\
\hline Poland & 99 & 97 & 2 & 3 & 98 & 93 & 5 & 6 \\
\hline Portugal & 100 & 100 & 0 & 0 & & 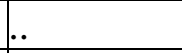 & .. & .. \\
\hline Romania & 100 & 89 & 11 & 13 & 98 & 81 & 17 & 21 \\
\hline Russian Federation & 100 & 89 & 11 & 13 & . & .. & .. & .. \\
\hline Slovak Republic & $\theta$ & .. & .. & .. & .. & .. &.. & .. \\
\hline Slovenia & 95 & 100 & -5 & -5 & 95 & 100 & -5 & -5 \\
\hline Ukraine &.. &.. & .. & .. & .. & .. & .. & .. \\
\hline \begin{tabular}{|l} 
Middle East \\
and North Africa \\
Algeria
\end{tabular} & 96 & 87 & 9 & 11 & 94 & 79 & 15 & 19 \\
\hline Egypt Arab Rep. & 95 & 78 & 17 & 22 & 95 & 67 & 28 & 42 \\
\hline Iran Islamic Rep. & 90 & 91 & -1 & -2 & 86 & 85 & 1 & 2 \\
\hline Jordan & 68 & 79 & -11 & -14 & 68 & 68 & 0 & 0 \\
\hline Lebanon & 76 & 92 & -16 & -18 &.. & .. & .. & .. \\
\hline Morocco & 74 & 80 & -6 & -8 & 66 & 69 & -3 & -5 \\
\hline Saudi Arabia & 60 & 100 & -40 & -40 & 57 & 100 & -43 & -43 \\
\hline Sudan & & .. &. & & .. & . & .. & .. \\
\hline Syrian Arab Rep. & 95 & 78 & 17 & 22 & 93 & 66 & 27 & 41 \\
\hline
\end{tabular}




\begin{tabular}{|c|c|c|c|c|c|c|c|c|}
\hline \multirow[t]{2}{*}{ Country } & \multicolumn{4}{|c|}{ Primary Enrollment Rate (PEN) } & \multicolumn{4}{|c|}{$\%$ Reaching Grade Five (TRG5) } \\
\hline & Actua & Expected & \begin{tabular}{|l|} 
NP \\
Absolute
\end{tabular} & $\begin{array}{l}\text { GEN } \\
\text { Relative }\end{array}$ & Actua & Expected & \begin{tabular}{|r} 
NP \\
Absolute
\end{tabular} & $\begin{array}{l}\text { GTRG5 } \\
\text { Relative }\end{array}$ \\
\hline Tunisia & 100 & 89 & 11 & 13 & 96 & 82 & 14 & 18 \\
\hline Turkey & 100 & 96 & 4 & 5 & 98 & 91 & 7 & 8 \\
\hline Yemen Rep. & & .. & .. &.. & |. & 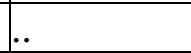 & .. & |. \\
\hline $\begin{array}{l}\text { Sub-Saharan Africa } \\
\text { Angola }\end{array}$ & 35 & 58 & -23 & -40 & 18 & 41 & -23 & -57 \\
\hline Benin & 68 & 60 & 8 & 14 & 52 & 44 & 8 & 19 \\
\hline Botswana & 80 & 98 & -18 & -19 & 76 & 94 & -18 & -20 \\
\hline Burkina Faso & 32 & 57 & -25 & -44 & 28 & 41 & -13 & -32 \\
\hline Burundi & 36 & 51 & -15 & -30 & 31 & 34 & -3 & -9 \\
\hline Cameroon & 62 & 67 & -5 & -8 & 50 & 52 & -2 & -4 \\
\hline Central Afr. Rep. & 46 & 62 & -16 & -26 & 18 & 47 & -29 & -62 \\
\hline Chad & 48 & 57 & -9 & -16 & 36 & 40 & -4 & -10 \\
\hline Congo Dem. Rep. & 58 & 54 & 4 & 8 & 42 & 38 & 4 & 11 \\
\hline Congo Rep. & 78 & 61 & 17 & 28 & 58 & 45 & 13 & 29 \\
\hline Côte d'Ivoire & 58 & 66 & -8 & -13 & 50 & 51 & -1 & -2 \\
\hline Eritrea & 29 & 59 & -30 & -51 & 24 & 42 & -18 & -43 \\
\hline Ethiopia & 35 & 49 & -14 & -29 & 24 & 32 & -8 & -25 \\
\hline Gabon & .. & .. & .. & .. & |. & .. & .. & .. \\
\hline Gambia & 66 & 64 & 2 & 4 & 60 & 48 & 12 & 25 \\
\hline Ghana & .. & .. & .. & .. & .. & .. & 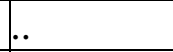 & .. \\
\hline Guinea & 46 & 68 & -22 & -33 & 41 & 53 & -12 & -23 \\
\hline Guinea Bissau & 52 & 55 & -3 & -6 & 18 & 39 & -21 & -54 \\
\hline Kenya & 65 & 60 & 5 & 9 & 53 & 44 & 9 & 21 \\
\hline Lesotho & 69 & 73 & -4 & -6 & 62 & 60 & 2 & 4 \\
\hline Madagascar & 61 & 56 & 5 & 9 & 36 & 39 & -3 & -8 \\
\hline Malawi & 99 & 52 & 47 & 91 & 51 & 35 & 16 & 46 \\
\hline Mali & 38 & 53 & -15 & -29 & 35 & 36 & -1 & -3 \\
\hline Mauritania & 57 & 67 & -10 & -15 & 45 & 52 & -7 & -14 \\
\hline Mauritius & 97 & 100 & -3 & -3 & 97 & 100 & -3 & -3 \\
\hline Mozambique & 40 & 52 & -12 & -24 & 26 & 35 & -9 & -26 \\
\hline Namibia & 91 & 91 & 0 & 0 & 81 & 84 & -3 & -4 \\
\hline Niger & 24 & 55 & -31 & -57 & 21 & 39 & -18 & -47 \\
\hline Nigeria & 59 & 55 & 4 & 8 & .. & .. & .. & .. \\
\hline Senegal & 60 & 66 & -6 & -10 & 56 & 51 & 5 & 10 \\
\hline Sierra Leone & 44 & 47 & -3 & -7 & & 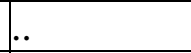 & .. & \\
\hline South Africa & 100 & 100 & 0 & 0 & 87 & 99 & -12 & -13 \\
\hline Tanzania & 48 & 50 & -2 & -4 & 43 & 33 & 10 & 31 \\
\hline
\end{tabular}




\begin{tabular}{|c|c|c|c|c|c|c|c|c|}
\hline \multirow[t]{3}{*}{ Country } & \multicolumn{4}{|c|}{ Primary Enrollment Rate (PEN) } & \multicolumn{4}{|c|}{ \% Reaching Grade Five (TRG5) } \\
\hline & \multirow[t]{2}{*}{ Actual } & \multirow[t]{2}{*}{ Expected } & \multicolumn{2}{|c|}{$N P G_{P E N}$} & \multirow[t]{2}{*}{ Actual } & \multirow[t]{2}{*}{ Expecteo } & \multirow{2}{*}{\multicolumn{2}{|c|}{$\begin{array}{c}\text { NPG }_{\text {TRG5 }} \\
\text { Absolute } \\
\text { Relative }\end{array}$}} \\
\hline & & & Absolute & Relative & & & & \\
\hline Togo & 82 & 65 & 17 & 27 & 68 & 50 & 18 & 36 \\
\hline Uganda & .. & . & [.. & . & 42 & 44 & -2 & -5 \\
\hline Zambia & 72 & 55 & 17 & 31 & 66 & 39 & 27 & 70 \\
\hline Zimbabwe & 93 & 73 & 20 & 28 & 83 & 60 & 23 & 39 \\
\hline
\end{tabular}

Sources:

World Bank, World Development Indicators 1997, 1998, 2000.

Unesco: World Education Report 1998, Statistical Yearbook 1999, and World Education Report 2000.

Unicef: State of the World's Children 2000.

.. Indicates that data were not available for the country. 
Table 4 National Performance Gap for the WINOCENT Child Welfare Index, 1995-98

\begin{tabular}{|c|c|c|c|c|c|}
\hline Country & WINOCENT & Country & WINOCENT & Country & WINOCENT \\
\hline Georgia & 42 & Benin & 4 & Colombia & -16 \\
\hline Croatia & 41 & Egypt Arab Rep. & 3 & Côte d'Ivoire & -16 \\
\hline Jamaica & 32 & Jordan & 3 & Indonesia & -17 \\
\hline Kyrgyzstan & 31 & Bangladesh & 1 & Morocco & -18 \\
\hline Albania & 31 & Honduras & -1 & Thailand & -19 \\
\hline Sri Lanka & 30 & Uruguay & -2 & Cameroon & -21 \\
\hline Mongolia & 25 & Panama & -4 & Venezuela & -22 \\
\hline Czech Republic & 25 & Algeria & -4 & Guinea Bissau & -22 \\
\hline Hungary & 25 & Tunisia & -4 & Ecuador & -24 \\
\hline Romania & 22 & Mali & -4 & Burkina Faso & -25 \\
\hline Malawi & 22 & Mozambique & -4 & Haiti & -28 \\
\hline Trinidad \& Tobago & 21 & Ethiopia & -5 & Turkey & -28 \\
\hline Nicaragua & 17 & Madagascar & -5 & Papua New Guinea & -30 \\
\hline Paraguay & 17 & Togo & -5 & Central Afr. Rep. & -30 \\
\hline Syrian Arab Rep. & 17 & Burundi & -6 & Mauritania & -31 \\
\hline Tanzania & 17 & Zimbabwe & -7 & Niger & -34 \\
\hline Costa Rica & 14 & Dominican Rep. & -8 & Angola & -36 \\
\hline Zambia & 14 & Senegal & -8 & Malaysia & -39 \\
\hline Gambia & 12 & Philippines & -10 & Mexico & -41 \\
\hline El Salvador & 8 & Chad & -10 & Guinea & -42 \\
\hline Congo Dem. Rep. & 8 & Lao PDR & -11 & Lesotho & -52 \\
\hline Chile & 7 & Mauritius & -11 & Guatemala & -59 \\
\hline Nepal & 7 & Bolivia & -12 & Namibia & -86 \\
\hline Congo Rep. & 7 & India & -13 & South Africa & -91 \\
\hline China & 5 & Eritrea & -13 & Botswana & -120 \\
\hline Kenya & 5 & Brazil & -14 & & \\
\hline Cambodia & 4 & Iran Islamic Rep. & -14 & & \\
\hline
\end{tabular}




\section{References}

Balderston, J.B. (1981) "Determinants of Children's School Participation". In J.B. Balderston, A.B. Wilson, M.E. Freire, M.S.Simeon, eds., Malnourished Children of the Rural Poor. Boston, M.A.: Auburn House Publishing Co.

Baltimore: John Hopkins University Press, pp. 204-5.

Basu, K. et al (1995) Choice, Welfare and Development: A Festschrift in Honour of Amartya Sen. Oxford: Oxford University Press.

Beasely, N.M.R. (1995) "A Study of Parasitic Helminth Infection and Iron Deficiency in School Age Children: Population Distribution and Dynamics of Interaction" Doctor of Philosophy thesis, University of Oxford, Center for Epidemiology of Infectious Disease, England.

Behrman, J., V. Lavy, and et al (1997) Child Nutrition, Child Health, and School Enrollment: A Longitudinal Analysis, Working Paper 97-021. Washington, D.C.: World Bank/Institute for Economic Reseach.

Behrman, Jere R. (1996) Human Resources in Latin America and the Caribbean, Washington D.C.: Inter-American Development Bank.

Bundy, D.A.P. (1997) "Health and Early Child Development." In M.E. Young, (ed.) Early Child Development: Investing in Our Children's Future. Proceedings of a World Bank Conference on Early Child Development: Investing in the Future, Atlanta, Georgia, April 8-9, 1996. Amsterdam, Holland: Elsvier.

Carnoy, M., et al. (1978) Can Education Equalize Income Distribution in Latin America? Geneva: International Labor Organization.

Chiswick, B., and J. Mincer, (1972) "Time-Series Changes in Personal Income Inequality in the United States from 1939 to 1985.” Journal of Political Economy 80.

Cochrane, S. (1980) The Effects of Education on Health, World Bank Staff Working Paper No. 405, Washington, D.C.: World Bank.

Dall, Frank (1995) "Children's Right to Education: Reaching the Unreached." In James Himes, (ed.) Implementing the Convention on the Rights of the Child: Resource Mobilization in Low-Income Countries. Florence, Italy: UNICEF, and London: Martinus Nijhoff Publishers.

Denison, E. (1962) The Sources of Economic Growth in the United States and the Alternatives Before the U.S. New York: Committee of Economic Development. 
Countries. Washington, D.C.: The Brookings Institution.

Glewwe, P. (1996) "The Relevance of Standard Estimates of Rates of Return to Schooling for Education Policy: A Critical Assessment," Journal of Development Economics 51(2):267-290.

Glewwe, Paul and Jacoby, Hanan (1995), "An Economic Analysis of Delayed Primary School Enrollment and Childhood Malnutrition in a Low Income Country" in Review of Economics and Statistics 77 (1), pp. 156-169.

Golden, M.H.N. (1994) "Is Complete Catch Up Possible for Stunted Malnourished Children?” European Journal of Clinical Nutrition 48 (Suppl. 1): S58-S71.

Grantham-McGregor, S., C. Powell, S. Walker, and J.H. Himes (1991) "Nutritional Supplementation, Psychosocial Stimulation, and Mental Development of Stunted Children: The Jamaican Study" Lancet 338:1-5.

Grantham-McGregor, S.M. (1990) "Malnutrition, Mental Function and Development." In R.M. Suskind, and L. Lewinter-Suskind, (eds.) The Malnourished Child. Nestle Nutrition Workshop Series 19. New York: Raven Press.

Hille, E.T.M. , A.L. Den Ouden, L. Bauer, C. van den Oudenrijn, R. Brand, and S.P. Verloove-Vanhorick (1994). "School Performance at Nine Years of Age in Very Premature and Very Low Birth Weight Infants: Perinatal Risk Factors and Predictors at Five Years of Age". Journal of Pediatrics 125:426-34.

Jamison, D. and P. Moock, (1984) "Farmer Education and Farm Efficiency in Nepal: The Role of Schooling, Extension Services and Cognitive Skills" World Development 12(1).

Jamison, Dean T. (1986), "Child Malnutrition and School Performance in China", in Journal of Development Economics 20 (2), pp. 299-331.

Johnsson, U. (1995) "Children's Right to Nutrition: Food, Care, and a Healthy Environment." In James Himes, (ed.) Implementing the Convention on the Rights of the Child: Resource Mobilization in Low-Income Countries. Florence, Italy: UNICEF, and London: Martinus Nijhoff Publishers.

Kravis, I., A. Heston, and R. Summers, (1978) United Nations International Comparison Project: Phase II; International Comparisons of Real Product and Purchasing Power.

Langoni, C. (1973) "Income Distribution and Economic Development in Brazil." Conjunctura Economica 27. 
Lasky, R.E., A. Lechtig, H. Delgado, R.E. Klein, P. Engle, C. Yarbrough, and R. Martorell, (1975) "Birth Weight and Psychomotor Performance in Rural Guatemala". American Journal of Diseases of Children 129:566-69.

Lockheed, M., D. Jamison, and L. Lau, (1980) "Farmer Education and Farmer Efficiency: A Survey" Economic Development and Cultural Change (29) 1.

Martorell, R., D.G. Schroeder, J.A. Rivera, and H.J. Kaplowitz, (1995) "Patterns of Linear Growth in Rural Guatemalan Adolescents and Children." Journal of Nutrition 125(4 Suppl.): 1090S-96S.

Martorell, R., J.A. Rivera, H. Kaplowitz, and E. Pollitt, (1992) "Long-Term Consequences of Growth Retardation During Early Childhood." Proceedings of the VIth International Congress of Auxology, Madrid, Spain, 15-19 Septermber 1991. In M. Hernandez, and J. Argente, (eds.), Human Growth: Basic and Clinical Aspects. Amsterdam, Holland: Elsevier.

Martorell, R., L.K. Khan, and D.G. Schroeder, (1994) "Reversibility of Stunting: Epidemiological Findings in Children from Developing Countries." European Journal of Clinical Nutrition 48 (Suppl. 1): S45-S57.

Pachico, D. and J. Ashby, (1976) "Investments in Human Capital and Farm Productivity: Some Evidence from Brazil." Study Prepared for Cornell University (processed).

Parker, David (1995) "Resources and Child Rights: An Economic Perspective." In James Himes, (ed.) Implementing the Convention on the Rights of the Child: Resource Mobilization in Low-Income Countries. Florence, Italy: UNICEF, and London: Martinus Nijhoff Publishers.

Patrick, G.F. and E.W. Kehlbern, (1973) "Education and Returns of Education in Five Agricultural Areas in Eastern Brazil" American Journal of Agricultural Economics (55)2.

Pollitt, Ernesto (1990) Malnutrition and Infection in the Classroom, Paris: UNESCO.

Psacharopoulos, G. and M. Woodhall, (1985) Education and Development: Analysis of Investment Choices. New York: Oxford University Press.

Psacharopoulos, George (1994) "Returns to Investment in Education: A Global Update." World Development 22(9):1325-44.

Saigal, S., P. Szatmari, P. Rosenbaum, D. Campbell, and S. King, (1991) "Cognitive Abilities and School Performance of Extremely Low Birth Weight Children and Matched Term Control Children at Age 8 Years: A Regional Study". Journal of Pediatrics 118:751-60. 
Satyanarayana, M.B., A. Nadamuni Naidu, and S. Narasinga Rao, (1980) "Agricultural Employment, Wage Earnings, and Nutritional Status of Teenage Rural Hyderabad Boys." Indian Journal of Nutrition and Diet 17: 281-86.

. (1979) "Nutritional Deprivation in Childhood and the Body Size, Activity, and Physical Work Capacity of Young Boys", American Journal of Clinical Nutrition 321:1769-75.

Schultz, T. (1961) “Investment in Human Capital” American Economic Review (51).

Sen, A. (1984) "Goods and People." In Amartya Sen, Resources, Values and Development. Cambridge, MA: Harvard University Press.

Simeon, D.T., and S.M. Grantham-McGrego, (1990) "Nutritional Deficienices and Children's Behavior and Mental Development" Research Review 3:1-24.

Smedler, A., G. Faxelius, K. Bremme, and M. Lagerstrom, (1992) "Psychological Development in Children Born with Very Low Birth Weight after Severe Intrauterine Growth Retardation: A 10-year Follow-up Study, Acta Paediatrica 81:197-203.

Spurr, G.B. (1988) "Body Size, Physical Work Capacity, and Producitivity in Hard Work: Is Bigger Better?" In J.C.Waterlow, ed., Linear Growth Retardation in Less Developed Countries, Nestle Nutrition Workshop Series 14. New York: Raven Press.

Spurr, G.B., J.C. Reina, and M. Barac-Nieto, (1983) "Marginal Malnutrition in Schoolaged Colombian Boys: Anthropometry and Maturation" American Journal of Clinical Nutrition 37:119-32.

Stjernqvist, K., and N.W. Svenningsen, (1995) "Extremely Low-Birth-Weight Infants Less than $901 \mathrm{~g}$ : Development and Behavior after 4 Years of Life", Acta Paediatrica 84:500-06.

UNESCO (2000) World Education Report 2000. Paris: UNESCO.

UNICEF (1996) Factors Influencing Female School Enrollment and Attendance. Ghana: UNICEF.

. (1993) Progress of Nations 1993. New York, N.Y.: UNICEF.

. (1995) Progress of Nations, New York, N.Y.: UNICEF

(1996) Progress of Nations 1996. New York, N.Y.: UNICEF. 
. (2000) State of the world's Children. New York: UNICEF.

Van der Gaag, Jacques (1997) "Early Child Development: An Economic Perspective."

In M.E. Young, ed., Early Child Development: Investing in Our Children's Future. Amsterdam, Holland: Elsvier.

World Bank (2000) World Development Indicators 2000. Washington, D.C.: World Bank. . (1995) Investing in Young Children. Washington, D.C.: The World Bank.

World Health Organization (2000) World Health Report 1999. Geneva: World Health Organization. 